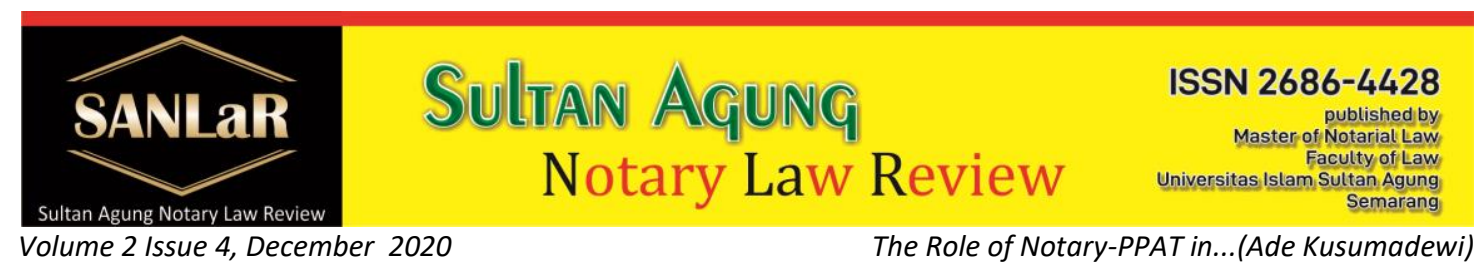

\title{
The Role of Notary-PPAT in the Implementation of Tax Payment Fraud Prevention
}

\author{
Ade Kusumadewi ${ }^{*}$ ), Gunarto ${ }^{* *}$ ), Maryanto $* * *$ ) \\ *) Student Master of Notary Law, Faculty of Law, Universitas Islam Sultan Agung \\ Semarang, Indonesia \\ E-mail: adekusumadewi95@yahoo.com \\ ${ }^{* *}$ Lecturer Master of Notary Law, Faculty of Law, Universitas Islam Sultan Agung \\ Semarang, Indonesia \\ ${ }^{* * *)}$ Lecturer Master of Notary Law, Faculty of Law, Universitas Islam Sultan Agung \\ Semarang, Indonesia
}

\begin{abstract}
This research has the following objectives: 1) To determine the role of the Notary/Land Deed Making Officer (PPAT) in the implementation of fraud prevention in connection with the Payment of Taxes/Tax Charges for Acquisition of Land and Building Rights (BPHTB) for the Implementation of the Process Sale and Purchase based on Authorization to Sell with the Object of the Sale and Purchase of Land and Buildings. 2) To find out the factors that arise to prevent fraud against fraud in the imposition of the tax burden on the acquisition of land and building rights (BPHTB). Method used in this research is empirical juridical method. Research using the empirical juridical method is research on the effect of the law on society. This study uses primary data sources and secondary data sources. Primary data sources are sources obtained from field research, while secondary data sources consist of primary legal materials, secondary legal materials, and tertiary materials. Then the data were analyzed qualitatively. The research results show that: 1) The authority of the recipient of the power of attorney cannot be proven in real or not valid, unless it is proven by the existence of a salepurchase agreement (PPJB) which contains the word paid. Because then it can be proven that the party is really the buyer. If it is not attached with a Sale-Purchase Deed (PPJB), it is feared that it will be misused or used by those who wish. In accordance with Article 1320 (KUHPerdata) regarding the validity of an agreement between the power of attorney and the grantor of power. Where in the process of transfer of name or request for sale and purchase certificates due to the transfer of rights to land and buildings, one of the conditions that must be fulfilled by the cliet or certificate application is the settlement of tax payments, who are burdened with taxes in the process of transferring rights to land and buildings, namely Seller and Buyer. Buyers are subject to tax burdens in the form of Fees for Acquisition of Land and Building Rights (BPHTB). So the role of the Notary/PPAT Officer is very much needed to minimize the existence of fraud that can result in losses for the Notary/Land Deed Making Official itself. 2) Preventing Factors for Notary Officers or Land Deed Making Officials (PPAT) so that there is no misuse of the power of sale and purchase of land in relation to the tax burden on the acquisition of land and building rights (BPHTB), including: a) Making a statement letter under the above hand stamp 6000, and inserted in the document; b) Photos of the parties; $c$ ) Closed-Circuit Television (CCTV); d) Fingerprints of the parties; e) Receipt in full for the sale of land which must be written by the party itself; and f) Providing a moral message to the parties so that their actions are truly honest, containing: (1) That the sale and purchase is based on the
\end{abstract}


principles of good faith and propriety; (2) Sale and Purchase conducted in a clear and cash manner; and (3) Please be honest about the number of transactions.

Keywords: Land Deed Maker Officials; Proxy of Sale and Purchase; BPHTB's Tax.

\section{Introduction}

In Indonesia, tax is a mandatory bill for individual taxpayers and corporate taxpayers that are useful for increasing state cash income or revenue for the state in order to increase the development of the country's infrastructure and improve the welfare of Indonesian people. Based on the provisions of the prevailing laws and regulations in Indonesia, any implementation of the transfer of rights to land and/or buildings is a Tax Object. The transfer of rights is subject to two taxes, namely from the seller and the buyer. Income Tax (PPh) is emphasized for the Seller and from the Buyer's side, the Tax on Acquisition of Land and Building Rights (BPHTB) is imposed. Activities subject to BPHTB and PPh taxes occur in land sale and purchase transactions for which there are rights.

Taxpayers are tax subjects who are subject to the obligation to pay taxes. Because those who are subject to tax are the parties who obtain the rights to land or buildings, the taxpayers are the parties who obtain the rights according to the acquisition of rights that occur. ${ }^{1}$ Subjects who are subject to BPHTB tax are private persons or entities that obtain rights to land and buildings, the subject of the BPHTB tax is also referred to as BPHTB taxpayers. Meanwhile, the object of BPHTB tax is the acquisition or receipt of rights to land and buildings from the transfer of land rights. ${ }^{2}$ In this case, the competent official will not authorize the acquisition of these rights before the taxpayers have paid or paid the BPHTB.

In relation to the existence of an area in the Earth's settlements and everything of value thereon, in implementing tax collection must have clear rules. Regulations relating to this tax are regulated in Act No. 12 of 1985 which has been amended by Act No. 12 of 1994 concerning Land and Building Tax (PBB). The basis for tax collection of Land and Building Rights Acquisition Fee (BPHTB) is Act No. 21 of 1997 concerning Tax on Acquisition of Rights on Land and Buildings issued on May 29, 1997, in the memory of the explanation stated, That land is part of the land is a gift from God Almighty and has a social function, and is also a very profitable investment tool. Apart from those who have rights to land and buildings, ${ }^{3}$

Especially with regard to taxes imposed on buyers, in the form of BPHTB, it is regulated in Act No. 21 of 1997 concerning Fees for Acquisition of Rights to Land and/or Buildings Jo. Law of the Republic of Indonesia Number 20 of 2000, Concerning amendments to

\footnotetext{
${ }^{1}$ Marihot P. Siahaan. (2003). Bea Perolehan Hak Atas Tanah dan Bangunan. Jakarta: Raja Grafindo Persada. p. 73

${ }^{2}$ Arie Prawira Sholeh. (2015). Penetapan Dan Pemungutan Pajak Daerah BPHTB. p. 7

${ }^{3}$ Memory of Explanation of Act No. 21 of 1997 concerning Fees for Acquisition of Land and Building Rights (BPHTB)
} 
Act No. 21 of 1997 concerning Fees for Acquiring Rights on Land and/or Buildings. In Article 1 paragraph (1) Act No. 20 of 2000 concerning Fees for Acquisition of Rights to Land and/or Buildings, it is formulated as follows: "Fees for the acquisition of rights to land and/or buildings are taxes imposed on the acquisition of rights to land and/or buildings referred to as tax. "

In implementing BPHTB payments when a person carries out a sale and purchase transaction of land and buildings then registers to obtain rights to land and buildings delegates his authority through a selling power against a Notary or PPAT which in practice the BPHTB tax collection by the authorized official sometimes does not match the market value should be borne by the seller or buyer of land or building.

\section{Research Methods}

The method used in this research is empirical juridical method. Research using the empirical juridical method is research on the effect of the law on society. This study uses primary data sources and secondary data sources. Primary data sources are sources obtained from field research, while secondary data sources consist of primary legal materials, secondary legal materials, and tertiary materials. Then the data were analyzed qualitatively.

In conducting data analysis, a qualitative analysis method is used, which is a research method that produces descriptive analysis data. Analysis descriptive data is data that is collected without using numbers and measurements, so that what the respondent states in writing or orally and what is researched and studied is something that is intact.

From the results of the research on the data obtained, then the data processing will be carried out with editing techniques, namely researching, matching the data obtained with regulations, jurisprudence, and scientific books that are related to the title raised. And using coding techniques, namely summarizing the data from interviews between respondents or parties related to this study by grouping them into certain predetermined categories.

\section{Results and Discussion}

\subsection{Notary The Role of Notaries/Land Deed Making Officials (PPAT) in the} Implementation of Prevention of the Exercise of the Power of Sale and Purchase of Land Related to Tax Expenses on Acquisition of Land and Building Rights (BPHTB)

In carrying out his profession, Notaries provide legal services to the public as regulated in Act No. 2 of 2014 concerning Amendments to Act No. 30 of 2004 concerning Notary Positions. With the enactment of this law, the Reglement op Het Notary Ambt in Indonesia/Notary Position Regulation in Indonesia (STb. 1860 Number 3) does not 
apply. The existence of a notary is ethically juridical, initially regulated in the Buergelijk Wetboek signs. ${ }^{4}$

Whereas the Official for Making Land Deeds in the mention of PPAT was first mentioned in Government Regulation Number 10 of 1961 concerning Land Registration (State Gazette of 1961 No. 28) mentioned by the term "Officer". Article 19 stipulates: ${ }^{5}$

Anyone who intends to transfer land rights, grant new rights to land, acquire land or lend money for land rights as a liability must be confirmed with a deed drawn up by and in the presence of an official appointed by the Minister of Agrarian Affairs.

This provision shows that written evidence made authentically by or before a Notary or Land Deed Making Official (PPAT) is in the area of civil law (private/private). This differs from the term "evidence" in criminal law or "documentary documents" in state administrative law or state administrative law which is commonly referred to as a decision letter (Beschikking), which is included in the area of public law. Authentic Written Evidence made by a Notary Public/PPAT differs from the purpose and legal basis of a decision letter made by state administrative officials in carrying out functions to carry out government affairs, both at the central and regional levels. ${ }^{6}$

The main task of the Notary/Land Deed Making Official (PPAT) is to make an authentic deed as for the word authentic based on article 1870 of the Civil Code (Buergelijk Wetboek), to provide it to parties that make it a perfect proof. Herein lies the importance of a Notary Public/PPAT, under Notary Public/PPAT because the law is given the authority to create a perfect means of proof, in the sense that what is stated in the authentic deed is basically considered true as long as there is no evidence to the contrary. ${ }^{7}$

Notary in carrying out its duties and authority to make deeds which are requested by the parties facing him, the Notary/PPAT must fulfill 4 Elements, namely: ${ }^{8}$
a. The Element of Truth;
b. Validity Element;
c. Completeness Element;
d. The Element of Clarity.

Regarding the authority that a notary/PPAT must have as a public official to make an authentic deed, a Notary may only operate in the area or territory designated for him and only in that area or jurisdiction is authorized (Article 18 UUJN).

Notary's authority is contained in Act No. 2 of 2014 concerning Amendments to Act No. 30 of 2004, which Habib Adjie divides into 3 domains of authority:

a. Notary Public Authority;

\footnotetext{
${ }^{4}$ Ngadino. (2019). Tugas dan Tanggung Jawab Jabatan Notaris di Indonesia. Semarang: Universitas PGRI Semarang Press. p. 4

5 Ngadino. (2019). Ketentuan Umum Tata Cara Pembuatan dan Pengisian Akta PPAT. Semarang: Universitas PGRI Semarang Press. p. 19

${ }^{6}$ Ngadino, op. Cit., p. 5

7 Arief Rachman, 2011, http://notarisarief.com/2011/05/15/otentisitas-suatu-akta-oetentik/, Accessed on November 4, 2020, at 19:54 WIB.

${ }^{8}$ Ngadino, op. Cit., p. 8
} 
Regulated in article 15 paragraph (1) of Act No. 30 of 2004 as amended by Act No. 2 of 2014 and the strength of evidence from a notary deed, conclusions can be drawn, among others:

1) The task of the notary is to formulate the wishes/actions of the parties into an authentic deed by taking into account and not violating applicable legal provisions; ${ }^{9}$

2) Authentic deed is a deed that has perfect legal force of proof and is binding for the parties so that the proof can stand alone and do not need to receive assistance and additional from other evidence ${ }^{10}$.

b. Notary's Special Authority;

Regulated in article 15 paragraph (2) of Act No. 30 of 2004 as amended by Act No. 2 of 2014, this authority includes:

1) Ratify the signature and determine the certainty of the date of the letter under the hand by registering in a special book;

2) Record letters under hand by registering in a special book;

3) Make a copy of the original letters under hand in the form of a copy containing the description as written and described in the letter concerned;

4) Conduct validation of the compatibility of the photocopy with the original letter;

5) Providing legal education in connection with making deeds;

6) Making deeds related to land; or

7) Create auction minutes. ${ }^{11}$

c. Authority to be determined later

It is regulated in article 15 paragraph (3) of Act No. 30 of 2004 as amended by Act No. 2 of 2014, which reads: "Apart from the authority referred to in article 15 paragraph (1) and paragraph (2), a notary has other powers regulated in statutory regulations ". This means that the increasing public awareness of the law, the more it will make people need perfect proof to anticipate and/or to resolve disputes that will occur in the future. ${ }^{12}$

Regarding the responsibilities of a Notary Public or PPAT as a public official relating to material truth, it is divided into 4 , among others: ${ }^{13}$

a. The responsibility of the Notary/PPAT for the material truth of the deed he makes;

b. Civil responsibility of the Notary/PPAT regarding the material truth in the deed he makes;

\footnotetext{
${ }^{9}$ Habib Adjie. (2008). Hukum Notaris Indonesia (Tafsir tematik Terhadap UU No. 30 Tahun 2004 Tentang Jabatan Notaris). Bandung: PT. Refika aditama. p. 78

${ }^{10}$ Ngadino, op. Cit., p. 20

${ }^{11}$ lbid, p. 10

${ }^{12}$ Ibid, p. 11

${ }^{13}$ Ibid, p. 12
} 
c. The responsibility of the Notary/PPAT based on the Notary Position Regulation and the Position of the Land Deed Maker regarding the material truth of the deed he makes

d. The responsibility of the Notary/PPAT in carrying out its office duties in accordance with the Code of Ethics.

The main task is an obligation that must be done, a worker who is a responsibility, an order to do or do something in order to achieve a goal. The main tasks are carried out by employees in an organization that provide an overview of the scope or complexity of the position or organization in order to achieve certain goals. ${ }^{14}$

Regarding the main duties of the Land Deed Making Official (PPAT) as stipulated in the provisions of Article 2 of Government Regulation Number 37 of 1998, among others:

a. The Official for Making Land Deeds has the main duty of carrying out some land registration activities by making deeds as evidence of certain legal actions regarding land or ownership rights over Apartment Units, which will be used as the basis for registering changes to land registration data as a result of this legal act;

b. (2) The legal actions referred to in paragraph (1) are as follows:
1) Buy and sell;
2) Exchange;
3) Grant;
4) Entry into the company (Inbreng);
5) Inclusion of common rights;
6) Granting of Building Use Rights/Use Rights to Freehold Land;
7) Granting Mortgage Rights;
8) Granting Power of Attorney to impose Mortgage Rights.

In general, the main duties of the Land Deed Making Official (PPAT) can be concluded:

a. Assisting parties who commit legal acts to apply for permits for transfer of rights and requests for confirmation of conversion and registration of land rights; $^{15}$

b. Make deeds regarding legal actions related to land rights and mortgage rights (Deed of Sale and Purchase, Swap Exchange)

Authority is a function to carry out activities within the organization, as the right to order others to do or not do something in order to achieve goals. Organizing is the process of preparing an organizational structure in accordance with the goals of the organization, its resources and the environment that surrounds it. ${ }^{16}$

The authority of the Land Deed Making Official, which in Dutch is called an autoriteit or gezag, is the power given by law to PPAT to make deeds, as referred to in article 3 and article 4 of Government Regulation Number 37 of 1998 concerning Land Deed Making Officials, among others:

a. Transfer of land rights;

b. Transfer of ownership rights over apartment units;

c. Assignment of land rights; and

\footnotetext{
${ }^{14}$ Muammar Himawan. (2004). Pokok-Pokok Organisasi Modern. Jakarta: Bina Ilmu, p. 38

${ }^{15}$ Boedi Harsono. (2000). Himpunan Peraturan-Peraturan Hukum Tanah. Jakarta: Djambatan, p.52

${ }^{16}$ lbid, p. 51
} 
d. The power of attorney imposes a mortgage.

In general, the powers of the PPAT include:

a. Make an authentic deed regarding all legal actions regarding:

1) Buy and sell;

2) Exchange;

3) Grant;

4) Entry into the company (Inbreng);

5) Inclusion of common rights;

6) Granting of Building Use Rights/Use Rights to Freehold Land;

7) Granting Mortgage Rights;

8) Granting Power of Attorney to impose Mortgage Rights.

b. PPAT can make deeds regarding legal actions of land rights (Hak Guna Usaha and Haka ex-Hak Milik Adat) or land rights which, according to their nature, can be transferred or rights over land which according to their nature can be transferred or encumbered with Mortgage Rights or Making a Letter Power to Impose Mortgage Rights;

c. The PPAT specifically only has the authority to make deeds regarding legal acts that are specifically mentioned in its appointment. ${ }^{17}$

The delegation of power to sell the house or land has been regulated in Civil Code (KUHPerdata) Article 1792. In the Civil Code, granting power of attorney is an agreement regarding a person who gives power to another person to carry out an affair.

However, in practice, for various reasons, the concept of light and cash is often not fulfilled. Not yet fulfilled, it does not mean that the transaction cannot be carried out, there are other instruments, namely the Sale and Purchase Agreement Deed ("PJB") as a binding, as a sign of the sale and purchase transaction, while waiting for the unsettled one. The requirements for the Sale and Purchase Deed have not been fulfilled, it could be because the payment has not been paid in full/in installments, the certificate is still in the process of being split or other processes, unable to pay taxes, or other legal conditions.

The Sale and Purchase Agreement Deed is made in 2 (two) versions, namely:

1) The new sale and purchase agreement deed are promises because usually the price has not been paid off (commonly referred to as: PJB Unsettled)

2) The Sale and Purchase Agreement Deed whose payment has been made in full, but the sale and purchase deed cannot be made in front of the authorized PPAT, because there is still an incomplete process, for example: still in the process of breaking the certificate, still in the process of merging and various reasons other reasons why the Sale and Purchase Deed cannot be made (commonly referred to as: PJB Lunas). ${ }^{18}$ Power to sell, can be included as a clause in the PJB, it can also stand alone, in the form of a separate deed. So, when signing, sign two deeds: the Sale and Purchase

\footnotetext{
${ }^{17}$ Ngadino, Ketentuan Umum Tata Cara Pembuatan dan Pengisisan Akta PPAT, op.Cit., p.34

18 https://www.hukumonline.com/klinik/detail/ulasan/lt548f3f2f8a900/pengikat-jual-beli-dan-kuasauntuk-menjual/, accessed on 26 October 2020
} 
Agreement and the Deed of Authorization to Sell. In the event that the power to sell is included as a clause in the Sale and Purchase Agreement, only the deed of the Sale and Purchase Agreement is signed.

This power of attorney only relates to matters for management. Meanwhile, to transfer objects or for a mortgage, it can only be done by the legal owner. This power of attorney can be invalid at any time or expire for several reasons.

1. The obligations of the grantor are as follows:

a. Fulfill the agreement made between the power of attorney and the grantor of power;

b. Returning the plot and costs that have been incurred by the beneficiary;

c. Paying wages to the recipient of power of attorney;

d. Providing compensation to the power of attorney for losses suffered while exercising his power of attorney;

e. Pay interest on the plot that has been issued by the recipient of attorney as of the issuance of the plot (Article 1807 to Article 1810 of the Civil Code)

2. Rights and Obligations of the Proxy

The right of the power of attorney is to receive services from the authorizer. The legal relationship that occurs between the power of attorney and the recipient will have legal consequences. Legal consequences, namely the emergence of rights and obligations of the parties. The obligations of the authorized person are presented as follows:

a. To exercise power of attorney and be responsible for all costs, losses, and interest arising from not exercising such power.

b. Completing matters that he had started doing at the time the authorizer died and could cause losses if not resolved immediately.

c. Responsible for all acts committed deliberately and negligence committed in exercising power.

d. Give a report to the power of attorney about what has been done, and give a calculation of everything he has received.

e. Responsible for another person appointed as his replacement in exercising his power:

1) If not given the power to appoint another person as his replacement;

2) If the power of attorney is given without mentioning a specific person, while the person chosen is in fact an incapable or incapable person (Article 1800 to Article 1803 of the Civil Code).

As has been clarified and/or clearly explained regarding the duties and authorities of the Notary/Notary Officer above as well as a little understanding of the authority of the power of attorney and authorizer above. The power of attorney is to receive results or services from the recipient of the power of attorney. That the Notary Or Land Deed Making Official has the authority to make Authentic Deeds which have Perfect legal force.

However, there is often miscalculation or "deliberately" miscalculating the Tax on the Acquisition of Rights on Land and Buildings (BPHTB) in the process of changing the name or making the Deed of Sale and Purchase of Land and Building. It is undeniable that in the process of bidding for land and/or buildings, it is often not passed the seller 
or the buyer directly, which often happens through "land brokers". Where in his activities "Land Broker" as the recipient of power from the seller and buyer of the land and building. What is often the case that in the process this broker acts arbitrarily without and/or without being aware of by the authorizer. So that the recipient of this power of attorney gets an advantage which causes a loss by the grantor of power.

According to Dr. Ngadino, SH, Sp.N, MH, the authority of the Power of Attorney cannot be proven in real or not valid, unless it is proven by the existence of a Sale-Purchase Deed (PPJB) which contains the word paid. Because then it can be proven that the party is really the buyer. If it is not attached with a Sale-Purchase Deed (PPJB), it is feared that it will be misused or used by those who wish. In accordance with Article 1320 of the Civil Code (KUHPerdata) regarding the validity of an agreement between the power of attorney and the grantor of power. Because if the Notary Public/Land Deed Making official (PPAT) is not thorough and firm, then one day if a Notary/PPAT dispute occurs, he can be sued for embezzlement due to his participation.

If there are other parties who do not belong to the party concerned, it is expected that they will leave or not in one room (one office), they are afraid of intervention from other parties (the broker), because in the application process that is heard is the request of the parties concerned. However, the broker often does not state his identity openly but rather covers being a party of Person A or Person B, so that the Notary Public/PPAT must strictly prohibit other parties with no direct relationship from participating. In this case what sometimes happens is in the process of Customs fees or the process of requesting a certificate.

Where in the process of transfer of name or request for sale and purchase certificates due to the transfer of rights to land and buildings, one of the conditions that must be fulfilled by the cliet or certificate application is the settlement of tax payments, which are taxed in the process of transferring rights to land and buildings, namely the seller. and Buyers. Buyers are subject to tax burdens in the form of Land and Building Rights Acquisition Fees (BPHTB) and sellers are subject to Income Tax (PPh).

In practice, the broker often takes advantage by exaggerating the duty tax burden, which causes material loss to the party giving the power of attorney, or the buyer may write down the nominal selling price below the price that should be paid in order to minimize the imposition of tax duties. In the field, the power of attorney often has an abundance of all matters as well as the requirements for the sale and purchase certificate application and Transfer of Name Fees, which is due to the applicant's busy schedule, this is where the opportunity for fraud in taxation often occurs.

Because the Notary/PPAT is also the one who has to pay the tax burden, if the payment of the tax burden is carried out by the buyer himself, the Notary does not want to attach or sign it to the tax bill for the acquisition of land and building rights (BPHTB), because it is feared that embezzlement will occur. buyer. Sometimes it is also possible for the broker to cooperate with a Notary Officer/PPAT to commit fraud in calculating the tax burden.

So the role of the Notary/PPAT Officer is very much needed to minimize the existence of fraud that can result in losses for the Notary/Land Deed Making Official itself. Because those who take into account the tax burden of the Land and Building Rights Acquisition Fee (BPHTB) are Notaries/Land Deed Making Officials (PPAT) so that the 
Notary/PPAT must act firmly and thoroughly who are the Parties involved and never want to cooperate with a broker even though it is a broker. official because it is detrimental to the Notary/PPAT with a criminal act of embezzlement because of his participation. Because in fact, in the process of calculating taxes and paying taxes, Notary/PPAT officials do not receive wages but bear a high risk. ${ }^{19}$

According to Wiwik Suhartiwi, $\mathrm{SH}, \mathrm{MH}$, he stated that fraud in the tax payment process could occur/could be done. For this reason, the Notary/PPAT must make a Sale and Purchase Deed and must be proven by signing a statement stating that it is true that the buyer and the seller have agreed to do so. And if there are other parties who participate in the process of making certificates or transfer fees for third parties, it is hoped that they will not be in one room at any time, including in the calculation of the Tax on Land and Building Rights Acquisition Tax (BPHTB). Because according to him, there is a concern for third party intervention.

To avoid things that are detrimental to the Notary/Land Deed Making Officer (PPAT), they must be firm, never want to or be tempted by offers that are lured by third parties who receive the power of attorney for their own benefit. Because as a Notary/Land Deed Making Officer (PPAT), in carrying out their duties and authorities, they must comply with the code of ethics and are always happy with their oath of office, so that everything can run smoothly and decisively in rejecting the offer.

Then in the process of making the Sale and Purchase Deed, the Notary must ask for a sale and purchase receipt so that if it is included in the deed, it is written in real terms. Because what is written in a notary deed must be registered in 5 (five) offices including the Tax Office so that if another party commits fraud for his own benefit the notary will not be dragged into a criminal act. ${ }^{20}$

\subsection{Preventing Factors The occurrence of misuse of the Power of Sale and Purchase of Land related to Tax Expenses on Acquisition of Rights on Land and Buildings (BPHTB)}

Preventing Factors for Notary Officers or Land Deed Making Officials (PPAT) so as not to cause misuse of the power to buy and sell land related to the tax burden on the acquisition of land and building rights (BPHTB), including:

a. Make a statement letter under hand on a 6000 stamp, and put it in the document;

b. Signing a Buyer Statement relating to the Imposition of Tax on Acquisition of Land and Building Rights (BPHTB) with a stamp of $6000 ;{ }^{21}$

c. Photos of the parties;

d. Closed-Circuit Television (CCTV);

e. Fingerprints of the parties;

f. Receipts in full for the sale and purchase of land which must be written by the party itself; and

g. Provide a moral message to the parties so that their actions are truly honest, containing:

\footnotetext{
${ }^{19}$ Interview with Dr. Ngadino, SH, Sp.N, MH, OnOctober 31, 2020, Monday, 11:20 WIB

${ }^{20}$ Interview with Mrs. Wiwik Suhartiwi, SH, MH, on November 9, 2020, Monday, 12: 00WIB

${ }^{21}$ Ibid, interview with Mrs. Wiwik Suhartiwi, $\mathrm{SH}, \mathrm{MH}$
} 
1) Whereas buying and selling is based on the principles of good faith and propriety;

2) Sale and Purchase conducted in a clear and cash manner; and

3) Please be honest about the transaction amount.

Based on the results of the above research, the authors argue that in order to prevent the abuse of the power of sale and purchase of land for the transfer of rights, the Notary Officer/Land Deed Making Officer (PPAT) must fulfill the points above and act decisively and openly. Because if there is fraud in the calculation of the BPHTB tax burden, the Notary/Land Deed Officials (PPAT) may be subject to criminal sanctions because their participation causes material and non-material losses.

\section{Closing}

Based on the results of research and discussion regarding the Role of Notary/Land Deed Making Official (PPAT) in the Implementation of Prevention of the Implementation of the Power of Sale and Purchase of Land Related to Tax Expenses on Acquisition of Land and Building Rights (BPHTB), conclusions can be drawn: 1) The power of attorney cannot proven in real terms or not valid, unless proven by the binding of sale-purchase deed (PPJB) which contains the word paid. Because then it can be proven that the party is really the buyer. If it is not attached with a SalePurchase Deed (PPJB), it is feared that it will be misused or used by those who wish. In accordance with Article 1320 (KUHPerdata) regarding the validity of an agreement between the power of attorney and the grantor of power. Where in the process of transfer of name or request for sale and purchase certificates due to the transfer of rights to land and buildings, one of the conditions that must be fulfilled by the cliet or certificate application is the settlement of tax payments, which are taxed in the process of transferring rights to land and buildings, namely the seller. and Buyers. Buyers are subject to tax burdens in the form of Fees for Acquisition of Land and Building Rights (BPHTB). So the role of the Notary/PPAT Officer is very much needed to minimize the existence of fraud that can result in losses for the Notary/Land Deed Making Official itself. 2) Preventing Factors for Notary Officers or Land Deed Making Officials (PPAT) so as not to abuse the power of sale and purchase of land in relation to the tax burden on the acquisition of land and building rights (BPHTB), including: a) Make a statement letter under hand with a stamp duty of 6000, and put it in the document; b) Photos of the parties; c) Closed-Circuit Television (CCTV); d) Fingerprints of the parties; e) Receipt in full for the sale of land which must be written by the party itself; and f) Providing a moral message to the parties so that their actions are truly honest, containing: (1) That the sale and purchase is based on the principles of good faith and propriety; (2) Sale and Purchase conducted in a clear and cash manner; and (3) Please be honest about the number of transactions, g) The Buyer must sign a statement of agreement on the imposition of Tax on Acquisition of Land and Building Rights (BPHTB) above 6000 stamp duty. 


\section{References}

Journals:

[1] Nurwulan, Pandam. (20019). "Shari'a Banking Agreement and Its Application in the Notary Deed According to the Law on Notary Position". Volume 25.

Books:

[1] Arie Prawira Sholeh. (2015). Penetapan Dan Pemungutan Pajak Daerah BPHTB

[2] Boedi Harsono. (2000). Himpunan Peraturan-Peraturan Hukum Tanah. Jakarta: Djambatan

[3] Marihot P. Siahaan. (2003). Bea Perolehan Hak Atas Tanah dan Bangunan. Jakarta: Raja Grafindo Persada

[4] Ngadino. (2019). Ketentuan Umum Tata Cara Pembuatan dan Pengisian Akta PPAT. Semarang: Universitas PGRI Semarang Press

[5] Habib Adjie. (2008). Hukum Notaris Indonesia (Tafsir tematik Terhadap UU No. 30 Tahun 2004 Tentang Jabatan Notaris). Bandung: PT. Refika aditama

[6] Muammar Himawan. (2004). Pokok-Pokok Organisasi Modern. Jakarta: Bina IImu

[7] Ngadino. (2019). Tugas dan Tanggung Jawab Jabatan Notaris di Indonesia. Semarang: Universitas PGRI Semarang Press

Internet:

[1] https://www.hukumonline.com/klinik/detail/ulasan/lt548f3f2f8a900/pengikatjual-beli-dan-kuasa-untuk-menjual/, accessed on 26 October 2020

[2] Arief Rachman, 2011, http://notarisarief.com/2011/05/15/otentisitas-suatuakta-oetentik/, Accessed on November 4, 2020, at 19:54 WIB.

Regulation:

Memory of Explanation of Act No. 21 of 1997 concerning Fees for Acquisition of Land and Building Rights (BPHTB)

Interview:

[1] Interview with Mrs. Wiwik Suhartiwi, SH, MH, on November 9, 2020, Monday, 12:00 WIB

[2] Interview with Dr. Ngadino, SH, Sp.N, MH, OnOctober 31, 2020, Monday, 11:20 WIB 